\title{
Bloggers and Deliberative Democracy in Indonesia's Blogosphere
}

\author{
M. Jacky ${ }^{1}$ \\ ${ }^{1}$ Sociology Department, State University of Surabaya, Indonesia \\ Correspondence: M. Jacky, Sociology Department, State University of Surabaya, Indonesia. E-mail: \\ jackyflinders@gmail.com
}

Received: November 5, 2014 Accepted: November 11, 2015 Online Published: November 23, 2015

doi:10.5539/ass.v11n28p15

URL: http://dx.doi.org/10.5539/ass.v11n28p15

\begin{abstract}
The study of the relationship between the Internet and democracy has produced two main debates. Some studies have said that the Internet has significantly contributed to democracy while others disagree. This study challenged the thesis of Habermas (2006) about the relationship between the Internet and Deliberative Democracy. This study was built on the following propositions: that the Internet causes bloggers to become parasitic, fragmented, and isolated; that it is effective in breaking down authoritarian regimes to create an egalitarian relationship, but it fails as a deliberative medium. This study used the concept of the public sphere and Habermas' Deliberative Democracy (2006). It also explored the use of 2.0 qualitative methods with a hacking analysis perspective. Moreover, it gained data from the Internet by using the latest version of $2.0 \mathrm{Web}$ and a virtual community. It focused on both discursive and non-discursive construction. The results of this study support only one of Habermas' three propositions: that the Internet creates egalitarianism. Thus, this study rejects Habermas' thesis apart from this one proposition. Furthermore, this study recommends that further research be done using the same propositions but on Twitter instead of the Internet.
\end{abstract}

Keywords: bloggers, blogosphere, deliberative democracy, online research

\section{Introduction}

There is a relationship between the public sphere and Deliberative Democracy. The public sphere was a major requirement for Deliberative Democracy (Habermas, 1994; Smuts, 2010). The public sphere was the arena of freedom and equality where citizens deliberated (Bohman \& Regh, 1998), and created public argument and responded through reason among fellow citizens (Cohen, 1989). Deliberative Democracy has decreased the political dominance of the government, parliament, judiciary and political parties. These bodies had previously determined public policy without a wider public's involvement. In contrast, Deliberative Democracy engaged public participation, especially the participation of marginal society (Ferree, 2002).

Habermas's public sphere was constructed by arguing facts from the 17th and 18th centuries in Europe in which the public sphere stood between civil society and the state. Civil society mediated between the state and private/corporate interests through public opinion and political practice (Sikka, 2006). Habermas defined the public sphere as people coming together as a public, claiming to be public, creating public authority itself, and engaging in public debate about government regulations relating to the public interest (Habermas, 1991a). In the public sphere, everyone participated without external pressure. Individuals used rational-critical debate and generated public opinion (Habermas, 1991b). Therefore, based on Habermas' view, the public sphere is the realm of communication for citizens to share opinions, express ideas, and publish public opinions autonomously without any pressure from the government and the owners of capital and free from personal interests whilst keeping the interests of the public at heart.

Habermas (1994) explained Deliberative Democracy. He said that informal public opinion-formation generated "influence"; influence was transformed into "communicative power" through the channels of political elections; and communicative power was again transformed into "administrative power" through legislation. It was the practice of democracy that emphasized deliberation among elements of society to influence political policy. Furthermore, deliberation emphasized the political participation of citizens to discuss political issues through rational arguments critically and aimed to reach consensus through communicative action. Through the resulting political discourse, citizens had political influence transformed into communicative power, and at some stage, became administrative power through legislation or policy. 
Habermas (2006) claimed that the Internet's effective use is to oppose authoritarian regimes, and that it hampers the freedom of public opinion and public spaces. Moreover, the Internet was not able to create an integrated community through consensus-building. In addition, bloggers were fragmented and isolated, so their voices could not directly influence policy. Habermas (2006) argued that the Internet only created a more egalitarian social life. However, Geiger (2009) rejected Habermas's claim that the Internet did not have a mechanism of collective action. The blogosphere mediated collective political action in society. The Internet websites Tehnocrati, Delicious, Digg and Google integrated bloggers and facilitated collective action among them. The blogosphere integrated the bloggers through both discursive and non-discursive construction. The Digg users could share non-discursively through algorithms to determine websites, blog posts, videos and other content to be displayed in accordance with their interests. Bruns (2007) and Rheingold (2007) disagreed with Habermas because he failed to read the phenomenon of political communication on the Internet. They argued that even though the public in the online community is so complex and diverse, individual participation is not lost in their offline activities. The bloggers either implicitly connected through joint membership or explicitly connected through a hyperlink posted throughout a variety of forums. The bloggers were connected through cross-linkage. Habermas believed that intellectuals were needed to focus public debate online; however, he downplayed blogs. In contrast, Burns (2007) believed that Wikipedia could perform the role of intellectuals. Furthermore, he thought that the Internet not only consisted of chatrooms but also contained many political discussion sites of various levels of rationality and civility, such as mailing lists, wikis, blogs, and message boards. Nevertheless, Habermas (2006) stuck to his thesis that the media became commercialized through the process of evolution from the print media to the telegraph and then the Internet. As a result, mass media had radically damaged the public space (Rheingold, 2007).

As mentioned previously, the study of the relationship between the Internet and democracy has produced two main debates. Habermas's first opinion, however, the second view that the Internet strengthens the democratic process, has been supported by several studies. Ó Baoill (2004) said that the Internet revived the flagging public sphere. According to Kahn \& Kellner (2004), and Kerbel \& Bloom (2005), the blogosphere encouraged civic engagement in politics. Schalken (2006) believed that the Internet contributed to democracy by creating its own public sphere. Smith (2005) concluded that the Internet increased civil liberties. In addition, Hague and Loader (1999) found that the Internet increased government accountability. Klein (2009) showed that social networking on the Internet increased. Lenk (1999), Mele (2005), and Prior (2009) concluded that the Internet increased participation and collective action. Furthermore, Geiger (2009), and Reedy \& Wells (2009) argued that the Internet improved democracy through the power of information because it involved many people. Morrisett (2003) and Rasmussen (2009) showed that the Internet supported bloggers' ability to deliberate, choose and act politically by providing information. Setälä \& Grönlund (2005) claimed that the Internet had a positive impact in generating more publicity. In conclusion, the Internet grows political will and facilitates citizen participation.

Nevertheless, Rasmussen (2009) thought that the Internet facilitated communicative action, and was different from mass media and face to face interactions. The Internet contributed to the local, national, and international public sphere. He believed that the Internet had fostered social capital by building information and membership in online and offline social networks. The Internet has connected individuals to create social mobilization for a common goal. Furthermore, Cummings \& Kraut (2002), Uslaner (2004), DiMaggio (2007), Rasmussen (2009), explained that the Internet improved social contacts. Lievrouw (2001), Shah (2001), Gershuny (2003), and Rasmussen (2009) found that activity on the Internet was not at the expense of offline interaction. The Internet has connected young people and encouraged interpersonal civic engagement across gender and age. However, Rasmussen accepted Habermas's thesis that the Internet played a secondary or marginal role in democracy. In fact, bloggers have had a political impact when mass media has taken their messages and exposed them to the general public. Rasmussen (2009) concluded that the model of an online public sphere in cyber-democracy was confusing. Nevertheless, Milliken, Gibson and O'Donnell (2008), Bimber (1998), and Gimmer (2001) argued that the Internet had the potential to enhance democracy through political discourse online that attracted public attention. The Internet has offered a contribution in building public opinion and engaging citizens in political discourse in the online public sphere, as well as providing information to the public space offline. For example, Dahlberg (2004), and Dahlgren (2005) found that emails, both public and private, blogs and websites supported the practice of democracy in the virtual public space.

Some researchers have agreed that the role of the Internet and democracy in Indonesia has had a long history. This statement has been supported by Marcus (1998), Tedjabayu (1999), Hill \& Sen (2000), Wong (2002), Lim (2002), Hill (2003), Nugroho \& Tampubolon (2008), and Nugroho (2009; 2011). For example, Tedjabayu (1999) and Wong (2002) reported that NGOs and journalists used the Internet to expose Human Rights issues and 
resisted the New Order regime. The Indonesian Forum for the Environment, or WALHI, used the Internet in 1989 and was followed by the Community Legal Aid Institute, or LBH, in 1990 (Tedjabayu, 1999). Furthermore, the Indonesian NGO, LBH, exposed the situation of Human Rights (HAM) in Apakabar (apakabar@clark.net), USA, to a United States based newsletter via the Internet. Apakabar was a real battleground between pro-democracy activists and supporters of Suharto's rule. In 1995, the LBH sent a message through Urgent Action (UA) to Apakabar protesting the killing of a female labor activist, Marsinah, who had led the workers' strike in East Java. Consequently, the fax machine of the office of the president of the Department of Foreign Affairs and the Ministry of Defence and Security was jammed by hundreds of faxes sent in protest from around the world (Wong, 2002).

In 1998-1999, the Internet played an important role in the development of democracy, in particular bringing down the New Order regime. Marcus (1998), Tedjabayu (1999), Wong (2002), Hill and Sen (2005), Lim (2006), believed that the Internet had an influence on the consolidation of democracy through particular means. Hill \& Sen (2005) indicated that the Internet and Internet café became a medium for activists to oppose the New Order regime. The Internet was used by young people and activists for social action and political coordination. The Internet was an efficient tool for activists to organize the movement, to mobilize action and to expand the network (Hill \& Sen, 2005). Ferdinand (2000) observed that the overthrow of President Suharto in 1998 was the first Internet revolution. The Internet became a space to articulate opposition to the status quo and the pro-free market. Ferdinand (2000) added that there were similarities between the infrastructure of the Internet café with the Habermasian eighteenth century public sphere where the public space was simultaneously a source of information, allowing people to share information, opinions and gossip, but, in contrast, the Internet was not structured, institutionalized, or censored. Marcus (1998) and Tedjabayu (1999) claimed that the Internet had become an alternative media that was free from the control of the New Order regime. When television, newspapers, magazines, and the radio were controlled by the regime, the Internet became an alternative media to disseminate information. Because the telephone was expensive, the activists protested via email. The fact of President Suharto's corruption was spread via email. The Activists used chat forums on the Internet to share tips against the military. In Indonesia, which consists of 17,000 islands, the Internet was a very effective means of political communication (Marcus, 1998).

From 2004-2011, there were changes to the Internet and political movements in Indonesia. In 2004, the Internet developed into Web 2.0 and was followed by the phenomenon of blogs (BlogSpot, WordPress), and social media (Facebook, YouTube, and Twitter). This changed both political action and, as a consequence, the political actors. Therefore, political movements were no longer monopolized by NGOs, journalists, and intellectuals. Moreover, bloggers became new political actors. In Indonesia, in 2007, the number of bloggers was around 25,000,000 (www.apjii.or.id). In 2011, according to CheckFacebook.com, the number of Indonesian facebookers was ranked second $(34,498,920)$ on Facebook with the United States ranked first $(148,867,700)$, and the United Kingdom ranked third $(28,080,160)$. Since then, bloggers have focused on micro-political issues, such as injustice, corruption, education, and environment. For example, Prita Mulyasari, who is a housewife and was a patient at the Omni International Hospital (OIH), was jailed after her complaints about her treatment about an email that she sent to friends. She was fined 204 million rupiah (US\$ 20,500) causing support for her to grow. A mailing list and Facebook group called "KOIN UNTUK PRITA" collected coins to help Prita to pay the fine. Knowing the huge support for Prita, OIH dropped the civil lawsuit. Another example followed with a Facebook group called "Gerakan 1,000,000 Facebookers Dukung Bibit \& Chanda" which helped to liberate Bibid and Chandra, who were chairmen of the Corruption Eradication Commission, or the KPK. Bibit \& Chandra were released from prison and returned to their roles as chairmen of the KPK.

This study answered the question: did the Internet encourage Deliberative Democracy in Indonesia? Specifically, this study answered three questions: firstly, did the Internet make bloggers parasitic to mainstream media and create a virtual public sphere that was not autonomous? Secondly, did the Internet encourage an egalitarian relationship among bloggers or legitimize democratic elitism? Thirdly, did the blogosphere mediate online deliberation and generate public opinion to influence policy? This study challenged the thesis of Habermas (2006) about the relationship between the Internet and Deliberative Democracy. He believed that the Internet was effective in breaking down authoritarian regimes and creating an egalitarian life, but it made bloggers become parasitic to mainstream media, so their public opinion could not influence constructed policy.

\section{Online Research Methods}

This study adapted "qualitative 2.0" research methods with a hacking analytical perspective. This method argued that research in virtual communities could not be equated with a study from the face -to-face environment (Bruckman, 2002a; 2002b; Frankel \& Siang, 1999; Jacobson, 1999). Some fundamental ethics could not be 
adapted in a virtual reality, such as the need for approval and the clarity of the subject (Hudson, 2005; Snee, 2008). The research on the Internet exposed the anonymous or pseudo anonymous presentation of the subject (Turkle, 1995; Branscomb, 1995; Reid, 2005; Danet, 1998; Curtis, 1992; Mnookin, 1996; van den Boomen, 1998). Some researchers looked at online anonymity where the subjects presented themselves more honestly and courageously (Hewson et al., 2003; Hookway, 2008). The demands of mainstream research ethics, such as the importance of the subject's request for approval, could hamper research, especially in large quantities. This was considered as SPAM. The mainstream research methods failed to understand the importance of developing a virtual reality and online research (Herring, 1996; King, 1996; Boehlefeld, 1996; Schrum, 1997; Frankel \& Siang, 1999; Eysenbach \& Till, 2001; Bassett \& O'Riordan, 2002; Bruckman, 2002a; Ess, 2002a; 2002b; Walther, 2002).

This study engaged national bloggers and international bloggers who are living in South Korea, Brazil, Berlin, Malaysia, Australia, Netherlands, Kuwait, United States, and Germany. The subjects of this study were divided into two types of bloggers. The first type was creator bloggers. These bloggers created an account or channel to support Bibit \& Chandra and to stop the criminalization of the KPK on Facebook, and YouTube. This study found 112 accounts to support Bibit \& Chandra on Facebook and 4 YouTubers who supported the KPK, namely: WongBusan, Mappln, Tvinilah, and Polittika. The second type was commentator bloggers. These bloggers actively commented and shared images and hyperlinks about the criminalization of the KPK on Facebook and YouTube. The data collection was carried out on the Internet from 2009-2012. This study used Internet Web 2.0 to collect data. Snee (2008) argued that there were three advantages in using Web 2.0 for social science research. Firstly, the user-generated content in the online environment was relatively easy to access. Next, daily life was being increasingly documented online. Finally, Web 2.0 created the quality and closeness of the relationship between researchers and research subjects.

Researcher makes a Facebook account and Youtube channel with none-anonymous and anonymous account to collect data. The research on anonymous account has been conducted by Glaser (2002) when he conducted research on racism in Internet. Researcher in this study used a full name and clear profile to build trust among Facebookers and Youtuber in none-anonymous account. Researcher joins and becomes friend with facebookers and youtuber to collect date derived from the individual account and group. Researcher is a participant observer who obtains data of the research subjects automatically as the effect of algorithms. Facebookers who update status on Facebook wall share info, a photo, video, friend, or group automatically linked into researcher account.

News feed and timeline as collected data are taken from facebookers' comments. The data on facebook profile are social status, economic and politics (status, region, age, education, work, political views, religion, music, games, or film). The data on a facebook photo are picture, photo and comments (like/ dislike). The data on a group or friend are membership of groups and links to blogosphere. Referring to the data, researcher can map social networking. The structure in Facebook gives strength in facebookers to spread the appropriate data: limited only to friends (friends only), everyone (everyone/ public), other friends (friends of friends) and adjust facebook setting (customize). By being a "friend" of facebookers, researcher can hack their data. Researcher tried not to give comments, take a side to build neutral relationship with Indonesian and Malaysian facebookers.

The approach on Youtube user is different from Facebook user, in which Facebook is focused on public, while Youtube channel are more private. By using Youtube search engine, it can be seen that channel with given video "angle" and later given an architectures such as like, dislike, share, flag as inappropriate and comment. Researcher looked at posting text, pictures, video and comments to see jargon files used by youtuber. Researcher also observes the movement or civil pattern of bloggers to link and share to the blogosphere. The bloggers make links to blog and other online media, namely detik.com, kompas.com, mediaindonesia.com, liputan6.com, Wordpress, Youtube and other online media.

\section{Result}

The Internet did not make bloggers parasitic to mainstream media. Habermas (2006) believed that bloggers were subordinated by mainstream media. In contrast, it encouraged them to be creative in organizing and making the virtual public sphere alive, both nationally and globally. The bloggers created the public sphere on Facebook and YouTube. The bloggers developed 155 threats to support Bibit \& Chandra or the KPK. One thread, which had a mass of 1,745,961 bloggers, supported Bibit \& Chandra on Facebook (see Figure 1). Wallsten (2007) found that the blogosphere was independent and different to mainstream media. The blogosphere was not bound by the authority of the state and corporate industry power (Barlow, 1996), and it connected the bloggers, who were geographically separated (O'Brien et al., 2000). They met online without being in the same geographical location. Wellman (2002) called this phenomenon "glocalisation." Therefore, the Internet produces a strong public sphere. 
It is independent. That is, it is not subordinated by mainstream media.

The bloggers constructed alternative public opinions and widely disseminated them without relying on mainstream media. They were not only consumers, but also the actors that created information without any censorship from any source (Hill \& Sen, 2005). Moreover, the Internet embedded confidence that the information that had been shared by bloggers was more accurate than mainstream media. For example, when the bloggers supported Bibit-Chandra, they believed more facts on "Fakta Kriminalisasi KPK" (faktakriminalisasi.wordpress.com, see Figure 2) than in mainstream media. The study found three public opinions. Firstly, corruption impoverished society, injured people's sense of justice and robbed public welfare. Secondly, Bibit and Chandra were a symbol of injustice. The bloggers believed that the KPK was disabled, and Bibit \& Chandra were detained, so that they could not investigate cases of corruption, specifically the Century scandal. The corruptors counter-attacked, though, through organized power, and the involvement of law enforcement agencies. Thirdly, the bloggers resisted injustice. The bloggers embedded the awareness of the importance of joining together, enforcing truth \& justice through the law, engineering action against corruptors, and throwing corruptors in prison.

This study believed Podhoretz (2002), and Johnson \& Kaye (2004) that bloggers possessed powerful political analysis and were more credible than mainstream media. In contrast to bloggers who didn't follow mainstream media, mainstream media watched political blogs (Roth, 2004; Drezner \& Farrell, 2004a; 2004b; Smolkin, 2004; Wallsten, 2007). Consequently, this study refutes the assumption of Habermas, Horkheimer, and Adorno that the control of material production controls ideas and the classes (Ubayasiri, 2006). As a result, the study rejected Gramsci, who argued that the dominant group had hegemony through inducing the consent of the majority lower class that were politically marginal (Hoare \& Smith, 1999). This study believes Cert (1999), Gates (1995), and Rheingold (1993) that the Internet was for everyone, giving individuals the opportunity to choose which balances the power between citizen and state. In addition, the Internet was a neutral medium rather than a mode of production (MacKenzie \& Wajcman, 1985; Bijker et al., 1993). In fact, mainstream media and the state have not subordinated and controlled bloggers.

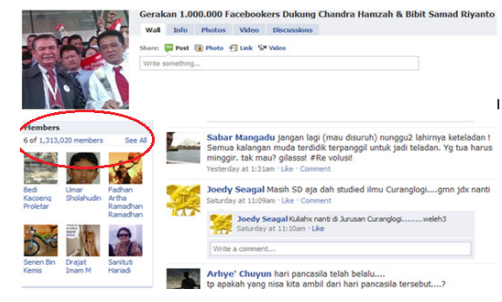

Figure 1

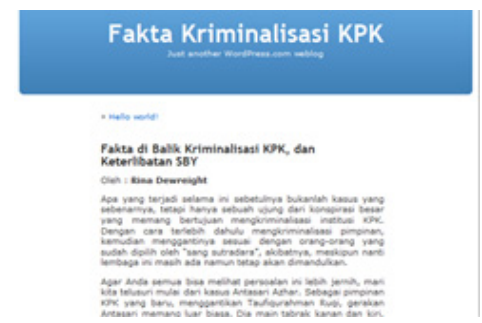

Figure 2

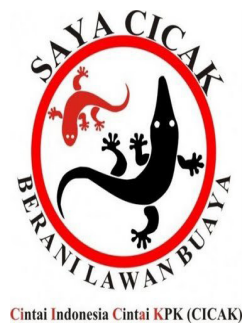

Figure 3

The bloggers used everyday language for deliberation. Their responses were diverse: rational, emotional and critical. Public opinions were constructed through petitions (rational), emotional statements (emotional), and investigative information (critical). The emotional bloggers' comments were "President SBY is inconsequential," "Police are Corrupt," "President SBY protects corruptors", "President SBY only gives lip service", "Politics is crushing the KPK", and "Corruptors cover the rot". The rational bloggers' comments were "The KPK has been criminalized, because the KPK investigated the Century case", "President SBY, Vice President Boediono and Finance Minister Sri Mulyani's case involved the Century scandal", "Chaos theory is being used to divert public attention", "President SBY is inconsistent," "Bibit \& Chandra should not be imprisoned but should be tried first and then given the right to justice"," Indonesian corruption is number one". The bloggers used the jargon file to portray grassroots society as a "lizard" fighting against the political elite, who were portrayed as a "crocodile", to raise public awareness (see Figure 3).

The emotional statements evoked group dynamics, participation and increased the arousal to comment. It suggested that bloggers engage in group discussions (Young, 1996; Sanders, 1997, Stokkom, 2003; Mansbridge et al., 2006). In contrast, when the rational criticism was monopolized by the elite and ignored the masses, it demeaned the silent masses, which then became more assertive and confrontational. Deliberation should not eliminate emotion as initiated by Habermas (2006) and developed by Cohen (1989), Manin (1987), Thompson \& Hoggett (2001), and Hershenov (2005). According to Habermas, irrational and emotional responses damage the judgment of deliberation (Rorty, 1985; Nussbaum, 1995; Sanders, 1997). Moreover, emotional responses did not 
make for poor deliberation (Hill \& Hughes, 1998; Wilhelm, 1999) but created an inclusive deliberation (Davis and Owen, 1998). It created people who talked directly and took decisions (Bessette, 1994; Chambers, 2004).

\subsection{E-Participation and Democracy Gap}

The Internet created egalitarianism across age, gender, ethnicity, community group, religion, education, and economic stratum. The Internet made bloggers' political involvement easier with e-participation which resulted in breaking the democracy gap. The Internet facilitated bloggers involved in political action through e-participation. This undermined the democracy gap. The blogosphere accommodated bloggers who were dispersed over 17,000 islands to support Bibit-Chanda. In fact, before the blogosphere, a public sphere could not be created in Indonesia, across regions, islands or the whole country. However, the bloggers who supported Bibit \& Chandra came from Jakarta, Surabaya, Yogyakarta, Makassar, Nusa Tenggara Barat, Pekanbaru, Medan, Pontianak, Riau, and Bengkulu. Furthermore, the study found that the international bloggers, who were living in South Korea, Brazil, Berlin, Malaysia, Australia, Netherlands, Kuwait, United States, and Germany, were actively involved in deliberation and the formation of public opinion as well.

The blogosphere has given bloggers a chance to participate through e-participation politics. There were five forms of e-participation. First, the bloggers commented collectively. They easily posted comments and statements and quickly received information (Sproull \& Faraj, 1995). Consequently, the Internet mediated democratic discourse (Corrado \& Firestone, 1996; Thornton, 2002). The grassroots could interact with political leaders in everyday language. Second, the bloggers listened to public opinion. The bloggers uploaded 43 videos on YouTube, which were heard by 55,412 people. Therefore, the bloggers were more enlightened (Burkhalter et al., 2002; Carpini et al., 2004; Melville et al., 2005, Warren, 1992). In addition, they were more engaged, empathetic, egalitarian, and inclusive (Mendelberg, 2002; Hickerson \& Gastil, 2008). Third, the bloggers built mass support. On Facebook and YouTube, the bloggers 'liked' their desired opinion and 'disliked' the opinions they rejected. Fourth, the bloggers shared public opinion. The bloggers spread public opinion through sharing, TAG, and SPAM. Actually, the Internet increased the flow of political activity under the power of information and ideas (Keck \& Sikkink, 1998; Klein, 1999; Geiger, 2009; Reedy \& Wells, 2009). The bloggers involved in information sharing made democracy more healthy (Barber, 1984; Pateman, 1970; Betsill \& Bulkeley, 2004). Fifth, the bloggers marginalized public opinion. They vindicated social reality through an inappropriate flag, and hid and removed public opinion that was considered wrong. In fact, the Internet provides deliberation and action, and Deliberative Democracy (Morrisett, 2003; Rasmussen, 2009).

The blogosphere decreased the democracy gap. In the 1990s, the political movement was dominated by NGOs, intellectuals, and journalists. This study agreed with Habermas (2006) that the Internet created an egalitarian society. The Internet engaged the grassroots populace in the democratic process (Rheingold, 1993; Davis \& Owen, 1998; Coleman, 2005). The blogosphere facilitated bloggers to meet, interact and make critical political communication (Fraser, 1992). This was not offered in the traditional mass media (Brundin, 2008) or in the offline public sphere, such as coffee shops, campuses, and "istighotzah." These have been dominated by NGOs, intellectuals, journalists, and elite religious organizations such as Nahdlatul Ulama and Muhmmadiyah. In contrast, the blogosphere provided opportunities to engage and expand the mass base (Blumler \& Gurevitch, 2001; Gimmler, 2001; Papacharissi, 2002a; 2002b). The blogosphere eliminated the ruling elite through the involvement of many people (Grönlund, 2001; Geiger, 2009; Reedy \& Wells, 2009).

The Internet eases bloggers involved in political activities through e-participation to decrease democracy gap. The blogosphere confronts Indonesian and Malaysian bloggers in a debate only through the social media. Internet encourages civil involvement in politics (Kahn \& Kellner, 2004; Kerbel \& Bloom, 2005). Internet increases individual participation and collective action (Lenk, 1999; Mele, 2005; Prior, 2007). The Internet is not only to create an egalitarian culture among bloggers, but also reverse democracy dominated by the elite, activists, students, intellectual, NGO's, reporters, politicians, political party, and other religious organizations. The bloggers involved in movement of supporting Bibit-Chandra and reclaiming identity Indonesia-Malaysia are from the various social background, regional, ages, education. The advantage of internet is that people can engage in the public space without having a physical mobilization.

The bloggers spread public opinion in the blogosphere with "share, TAG, SPAM"device. The bloggers depend on the strength of information and ideas (Keck \& Sikkink, 1998). The blogosphere culture, bloggers easily spread public opinion with a device "share and tag". The opinion will be considered as right and represent bloggers' voice which is freely shared. Sunstein (2001) said that deliberation on the internet only for those who have same views. They believe that bloggers stuck into wall discussion makes their voices echoes. The wall in the Internet will filter the different views and close the same one. Sunstein (2001) also reminds that though Internet offers 
various views and identity, blogger just tries to get information and interacts to strengthen their ideas, avoids communicating with different view-owned by other bloggers. Research conducted by Wilhelm (1999) shows that blogger will lead to strong dispute and generally the bloggers' arguments follow the previous same argument.

Filtering conducted by internet users has an impact on limited views and identity. The debate on the Internet was running only for them who have the same thoughts and identity. Sunstein (2001) stated that Internet contributes to community fragmentation or deliberative fragments. The deliberative fragments lead to the polarization among different groups. Sunstein (2001) stated about polarization that it will restrict society to understand each other from a different view and increase enmity and even violent and also threaten democracy.

This study produces a different proposition from Habermas et al. Deliberative Online in the Internet, by taking the theme of supporting Bibit-Chandra and reclaiming identity produces a proposition that deliberative online in the Internet has multiple ratios, both the critical and emotional ratio and has a daily language discourse. The deliberative online frequently appears in the form of the consensus and dissensus; for instance, Bloggers tend to meet the consensus on morality issue, for instance; anti-corruption, but they tend to have dissensus on the issues of identity. This study also found that bloggers were very critical and disorient to conquer the regime.

The blogosphere builds virtual solidarity. The spirit of eliminating deliberative fragments makes opinion to be listened by the society. The blogosphere contrasts with assumption of Habermas and Sunstein (2001) who believes that the Internet isolates bloggers from the community to share their views for their own surrounding and isolate from the different views of other bloggers. On the contrary, the blogosphere is appropriate with Bruns (2007) that membership in online community is so complex, diverse of participation and an individual does not lose activities in the context of offline. The virtual community is not isolated because their members are connected through membership and through the hyperlink connecting the posting in the forum. The blogosphere equipped with hypertext and hyperlink has facilitated social relations through cross-linkage (Bruns, 2007).

Customizing communication on online device at the blogosphere is not increase people ability to hear their own voice and avoid communication from others as Sunstein feared. Segregation in the blogosphere feared by Sunstein is eroded by hyperlink that pierce bloggers wall. Hyperlink has integrated bloggers to traditional media, blog, social networking, other bloggers account. Besides hyperlink, the blogosphere are equipped with a device "like, comment, share (LCS)" that allows bloggers have the mutual comment, support, and share public opinion, also discourse public in the form of text, photos, video systematically and sustainable, and documented regularly. This phenomenon is not separation but aggregation for bloggers.

Thus, this study rejected the idea of Sunstein (2001) that puts negative effect of any person customizing themselves in the Internet. It rejected proposition that the Internet increases any person's ability to hear reverberation of voice and walls from the other (Sunstein, 2001). He stated that the Internet weaken democracy as it enables the community to isolate themselves in the group to share their views and experience and reject the information that may be contrary to their belief, a phenomenon known as "cyberbalkanization" or political polarization.

The bloggers spread the public opinion and public discourse in the form of a photograph or video to wall of bloggers massively. It is different from share that infects news feeds of bloggers, tag device get into wall of bloggers which is so private. With "tag" device, public opinion spreads collectively which has the opportunity to be greeted and read. The blogosphere with algorithms aggregation meets both parties with different discourse attacking and disputing each other.

\subsection{The Power of Public Opinion}

Public opinion was built by bloggers who had the power to influence political policy by enlarging its mass base and public consent. Bibit and Chandra were released through the reopening of the KPK and reoccupied their positions. The bloggers used public opinion as a "weapon" to fight corruption. This study supported the idea of Tilly (1978) and Mele (2005) that public opinion is a victim of arbitrary rule and that, for this reason, injustice must be encouraged for collective action to influence political policy. The bloggers used the blogosphere to express public opinion (Allan, 2006). The bloggers were transformed from being mere spectators and players involved in the making of meaning (Coleman, 2005) thus affecting the flow of information and helping bloggers interpret and predict political events. The main strength of blogging was to find appropriate information so as to establish a considered point of view. They produced information and public opinion based on political events and then amplified this information through social networks which stole the attention of governments and even entered into the mainstream media.

This study clearly refused the claims that internet create the democracy gap indicated by the poor response. The 
bloggers accustomed to uploading public opinion in the form of video and other bloggers listening. The from the uploaded 96 video on Youtube in the theme of reclaiming the identity of Indonesia-Malaysia is heard or at least greeted 5.350.863 good bloggers of Malaysia and Indonesia. While from 43 video uploaded by bloggers in the theme of supporting Bibit-Chandra is heard by 55.412 Indonesian bloggers. While listening the voice such as the "cry" of bloggers, the blogosphere also provides a device that can be attracted gain support and denials, even marginalize the unwanted public opinion. On the contrary, the bloggers give support (like) each other or a refusal (dislike) against public opinion. From 26 video on Youtube uploaded by bloggers in the theme of reclaiming identity, gets 651 supports and 356 oppositions of bloggers both from Malaysia and Indonesia.

The Internet offers alternative ways for the bloggers to participate in politics without leaving house or workplace, or delaying on scheduled travel and other activities. The political participation can be done in the private (at home) with the help of the Internet. By pressing "click" item, bloggers engage to in participation, called political "click-activism".

The blogosphere provides freedom to bloggers to produce and reproduce public opinion in form of statement, comments, photo or video. The blogosphere provides opportunity to bloggers to participate by supporting (like), and spreading public opinion which is intended and refuse (dislike), mark (flag as inappropriate), hide, even remove the unwanted public opinion. Through online deliberations, researchers not only enlighten bloggers but also increase citizens' participation in general (Burkhalter et al., 2002; Carpini et al., 2004; Melville et al., 2005; Warren, 1992; Hickerson \& Gastil, 2008). E-participation such as listening to others with empathy, as stated by Mendelberg, he extended the public interest with more egalitarian views, an open mind and argument" (Mendelberg, 2002). The bloggers listen to the public opinion which is built and spread through a video.

\section{Conclusion}

In conclusion, this study found a relationship between the Internet and Deliberative Democracy. Therefore, it is believed that Internet did not make bloggers parasitic to mainstream media. In fact, the bloggers created 155 virtual public spheres both nationally and globally to support Bibit \& Chandra. Moreover, they produced alternative public opinions and reinforced the truth that their opinion was fact. The bloggers produced three discourses in the blogosphere. Firstly, corruption impoverished society, injured the people's sense of justice and robbed public welfare. Next, the criminalized Bibit \& Chandra were a symbol of injustice. They were represented by the lower class (lizard) and opposed the class elite (crocodile). Finally, the bloggers resisted injustice. The bloggers shared their opinion in the blogosphere (Facebook, YouTube and so on). They deliberated through shared comments, TAG photos, created videos, and polling. In addition, the bloggers created petitions, collective consciousness, and formed demonstrations. Their deliberation promoted a court of public opinion.

\section{References}

Allan, S. (2006). Online News. Maidenhead: Open University Press.

Barber, B. J. (1984). Strong Democracy: Participatory Politics for a New Age. Berkeley, CA: University of California Press.

Barlow, J. (1996). A Declaration of the Independence of Cyberspace. Retrieved from https://projects.eff.org/ $\sim$ barlow/Declaration-Final.html

Bassett, E. H., \& O'Riordan, K. (2002). Ethics of Internet Research: Contesting the Human Subjects Research Model. Ethics and Information Technology, 4(3), 233-247. http://dx.doi.org/10.1023/A:1021319125207

Bessette, J. M. (1994). The Mild Voice of Reason. Chicago: University of Chicago Press.

Betsill, M. M., \& Bulkeley, H. (2004). Transnational Networks and Global Environmental Governance: The Cities for Climate Protection Program. International Studies Quarterly, 48(2), 471-493. http://dx.doi.org/10. 1111/j.0020-8833.2004.00310.x

Bijker et al. (Eds.). (1993). The Social Construction of Technological Systems: New Directions in the Sociology and History of Technology. MIT Press, First MIT Paperback edition., Cambridge.

Bimber, B. (1998). The Internet and Political Transformation: Populism, Community and Accelerated Pluralism. Polity, 31(1). http://dx.doi.org/10.2307/3235370

Blumler, J. G., \& Gurevitch, M. (2001). The New Media and Our Political Communication Discontents: Democratizing Cyberspace. Information, Communication \& Society, 4(1), 1-13. http://dx.doi.org/10. $1080 / 713768514$

Boehlefeld, S. P. (1996). Doing the Right Thing: Ethical Cyberspace Research. The Information Society, 12(2), 
141-152. http://dx.doi.org/10.1080/713856136

Bohman, J., \& Rehg, W. (Eds.). (1998). Deliberative Democracy: Essays on Reason and Politics: Studies in Contemporary German Social Thought. Massachusetts: MIT Press.

Branscomb, A. W. (1995). Anonymity, Autonomy, and Accountability: Challenges to The First Amendment In Cyberspaces. Yale Law Journal, 104, 1639-1679. http://dx.doi.org/10.2307/797027

Bruckman, A. (2002a). Studying the Amateur Artist: A Perspective on Disguising Data Collected in Human Subjects Research on the Internet. Internet Research Ethics. Retrieved from http://www.nyu.edu/projects /nissenbaum/ethics_bru_full.html

Bruckman, A. (2002b). Ethical Guidelines for Research Online. Retrieved from http://www.cc.gatech. $\mathrm{edu} / \sim \mathrm{asb} / \mathrm{ethics}$

Brundin, P. (2008). Politics on the Net: NGO Practices and Experiences. Örebro University.

Bruns, A. (2007). Habermas and/Against the Internet. Snurblog. Retrieved from http://snurb.info/node/621

Burkhalter, S., Gastil, J., \& Kelshaw, T. (2002). A Conceptual Definition and Theoretical Model of Public Deliberation in Small Face-to-Face Groups. Communication Theory, 12, 398-422.

Carpini, M. X. D., Cook, F. L., \& Jacobs, L. R. (2004). Public Deliberation, Discursive Participation, and Citizen Engagement: A Review of the Empirical Literature. Annual Review of Political Science, 7, 315-344. http://dx.doi.org/10.1146/annurev.polisci.7.121003.091630

Chambers, S. (2004). Behind Closed Doors: Publicity, Secrecy, and the Quality of Deliberation. Journal of Political Philosophy, 12, 389-410. http://dx.doi.org/10.1111/j.1467-9760.2004.00206.x

Cohen, J. (1989). Deliberation and Democratic Legitimacy. In P. Pettit, \& A. P. Hamlin (Eds.), The good polity. New York: Basil Blackwell.

Coleman, S. (2005). Blogs and The New Politics of Listening. Political Quarterly, 76(2), 272-280. http://dx.doi. org/10.1111/j.1467-923X.2005.00679.x

Corrado, A., \& Firestone, C. M. (Eds.). (1996). Elections in Cyberspace: Towards a New Era in American Politics. Washington, DC: Aspen Institute.

Cummings, J. N., \& Kraut, R. (2002). Domesticating Computers and the Internet. The Information Society, 18(3), 221-231. http://dx.doi.org/10.1080/01972240290074977

Curtis, P. (1992). Mudding: Social Phenomena in Text-Based Virtual Realities. Retrieved from http://www.eff. org/pub/Net_culture/MOO_MUD_IRC/curtis_mudding

Dahlberg, L. (2004). Net-public sphere research: Beyond the 'first phase'. Javnost, 11(1), 27-43. http://dx.doi. org/10.1080/13183222.2004.11008845

Dahlgren, P. (2005). The Internet, Public Spheres, and Political Communication: Dispersion and Deliberation. Political Communication, 22, 147-162. http://dx.doi.org/10.1080/10584600590933160

Danet, B. (1998). Text as a Mask: Gender, Play and Performance in the Internet. In S. Jones (Ed.), 1998, Cybersociety 2.0: Revisiting Computer Mediated Communication and Community. Thousand Oaks, CA: Sage Publications. http://dx.doi.org/10.4135/9781452243689.n5

Davis, R., \& Owen, D. (1998). New Media and American Politics. Oxford: Oxford University Press.

Drezner, D. W., \& Farrell, H. (2004a). The Power and Politics of Blogs. The annual conference of the American Political Science Association.

Drezner, D. W., \& Farrell, H. (2004b). Web of Influence. Foreign Policy, 145, 32-40. http://dx.doi.org/10. $2307 / 4152942$

Ess, C. (2002a). Ethical Decision-Making and Internet Research: Recommendations from the AoIR Ethics Working Committee. Association of Internet Researchers (AoIR).

Ess, C. (2002b). "Introduction" Internet Research Ethics. Retrieved from http://www.nyu.edu/projects/nissen baum/ethics_ess_full.html

Eysenbach, G., \& Till, J. (2001). Ethical Issues in Qualitative Research on Internet Communities. BMJ, 323, 1103-1105. http://dx.doi.org/10.1136/bmj.323.7321.1103

Ferdinand, P. (2000). The Internet, Democracy and Democratization. London: Frank Cass. 
Frankel, M. S., \& Siang, S. (1999). Ethical and Legal Aspects of Human Subjects Research on the Internet. Paper given at American Association for the Advancement of Science workshop, June 10-11, 1999 Conference. Retrieved from http://www.aaas.org/spp/dspp/sfrl/projects/intres/main.htm

Fraser, N. (1992). Rethinking the Public Sphere: A contribution to the Critique of Actually Existing Democracy. In C. Calhoun (Ed.), Habermas and the Public Sphere. Cambridge, MA: MIT Press.

Gates, B. (1995). The Road Ahead. New York, Viking.

Geiger, S. (2009). Does Habermas Understand the Internet? The Algorithmic Construction of the Blogo/Public. Gnovis: A Journal of Communication, Culture, and Technology, 10(1).

Gershuny, J. (2003). Web Use and Net Nerds: A Neofunctionalist Analysis of the Impact of Information Technology at Home. Social Forces, 82(1) 141-168. http://dx.doi.org/10.1353/sof.2003.0086.

Gimmler, A. (2001). Deliberative Democracy, the Public Sphere and The Internet. Philosophy \& Social Criticism, 27(4). http://dx.doi.org/10.1177/019145370102700402.

Glaser, J. et al. (2002). Studying Hate Crime with the Internet: What Makes Racists Advocate Racial Violence? Journal of Social Issues, 58(1). http://journals.ohiolink.edu:20080/local-cgi/sendpdf/0205071407254431 28.pdf

Grönlund, K. (2001). Do new ICTs demand more responsive governance? European Consortium for Political Research Workshop. Grenoble, April. Retrieved from http://www.essex.ac.uk/ecpr/jointsessions/grenoble/ papers/ws3.htm

Habermas, J. (1991a). The Public Sphere. In C. Mukerji, \& M. Schudson (Eds.), Rethinking Popular Culture. Berkeley: University of California Press.

Habermas, J. (1991b). The Structural Transformation of the Public Sphere: An Inquiry Into a Category of Bourgeois Society (Studies in Contemporary German Social Thought). Cambridge, MA: MIT Press.

Habermas, J. (1994). Three Normative Models of Democracy. In S. Benhabib (Ed.), Democracy and Difference: Contesting the Boundaries of the Political. Princeton, NJ: Princeton University Press. http://dx.doi.org/10. 1111/j.1467-8675.1994.tb00001.x

Habermas, J. (1996). Between Facts and Norms: Contribution to a Discourse Theory of Law and Democracy. Cambridge: MIT Press.

Habermas, J. (2006). Political Communication in: Does Democracy Still Enjoy an Episte mic Dimension? The Impact of Normative Theory on Empirical Research. Communication Theory, 16(4), 423. http://dx.doi.org $/ 10.1111 / \mathrm{j} .1468-2885.2006 .00280 . \mathrm{x}$

Hague, B. N., \& Loader, B. D. (Eds.). (1999). Digital Democracy: Discourse and Decision Maling in the Information Age. London: Routledge.

Herring, S. (1996). Linguistic and Critical Analysis of Computer-Mediated Communication: Some Ethical and Scholarly Considerations. The Information Society, 12(2), 153-168. http://dx.doi.org/10.1080/911232343

Hershenov, D. B. (2005). Two Epistemic Accounts Of Democratic Legitimacy. Polity, 37. http://dx.doi.org/ 10.1057/palgrave.polity.2300012

Hickerson, A., \& Gastil, J. (2008). Assessing the Difference Critique of Deliberation: Gender, Emotion, and the Jury Experience. Communication Theory, 18(2008), 281-303. http://dx.doi.org/10.1111/j.1468-2885. 2008.00323.x

Hill, D. (2003). Communication for a New Democracy: Indonesia's First Online Elections. The Pacific Review 16(4), 525-548. http://dx.doi.org/10.1080/0951274032000132245

Hill, D. T., \& Sen, K. (2005). The Internet in Indonesia's New Democracy. New York: Routledge.

Hill, D., \& Sen, K. (2000). Media, Culture and Politics in Indonesia. Oxford University Press, Oxford.

Hill, K. A., \& Hughes, J. E. (1998). Cyberpolitics: Citizen Activism in the Age of the Internet. Lanham, MD: Rowman \& Littlefield.

Hoare, Q., \& Smith, G. N. (Eds.). (1999). Selections from the Prison Notebooks of Antonio Gramsci. London: Lawrence \& Wishart. 
Hookway, N. (2008). Entering The Blogosphere Some Strategies For Using Blogs In Social Research. Qualitative Research, 8(1), 91-113. Los Angeles, London, New Delhi and Singapore: SAGE Publications. http://dx.doi.org/10.1177/1468794107085298

Hudson, J. M. (2005). Amy Bruckman, Using Empirical Data to Reason about Internet Research Ethics. Retrieved from http://www.cc.gatech.edu/fac/Amy.Bruckman/papers/hudson-bruckman-ecscw05.pdf

Jacobson, D. (1999). Doing Research in Cyberspace. Field Methods, 11(2). Sage Publications, Inc. http://dx.doi. org/10.1177/1525822X9901100204

Johnson, T. J., \& Kaye, B. (2004). Wag The Blog: How Reliance on The Traditional Media and The Internet Influence Credibility Perceptions of Weblogs Among Blog Users. Journalism and Mass Communication Quarterly, 81, 622-642. http://dx.doi.org/10.1177/107769900408100310

Kahn, R., \& Kellner, D. (2004). New Media and Internet Activism: From the 'Battle of Seattle' to Blogging. New Media and Society, 6(1), 87-95. http://dx.doi.org/10.1177/1461444804039908

Keck, M. E., \& Sikkink, K. (1998). Activists Beyond Borders: Advocacy Networks in International Politics. Ithaca, NY: Cornell University Press.

Kellner, D. (2004). The Media and the Crises of Democracy in the Age of Bush-2. Communication and Critical/Cultural Studies, 1(1), 29-58. http://dx.doi.org/10.1080/1479142042000180917

Kerbel, M., \& Bloom, J. (2005). Blog for America and Civic Involvement. Harvard International Journal of Press/Politics, 10(4), 3-27. http://dx.doi.org/10.1177/1081180X05281395

King, S. A. (1996). Researching Internet Communities: Proposed Ethical Gui delines for Reporting of Results. The Information Society, 12(2), 119-127. http://dx.doi.org/10.1080/713856145

Klein, H. K. (1999). Tocqueville in Cyberspace: Using the Internet for Citizen Associations. The Information Society, 15, 213-220. http://dx.doi.org/10.1080/019722499128376

Lenk, K. (1999). Electronic Support of Citizen Participation in Planning Processes Activity. In B. N. Hague, \& B. D. Loader (Eds.), Digital Democracy: Discourse and Decision Maling in the Information Age. London: Routledge.

Lievrouw, L. A. (2001). New Media and the Pluralisation of Life-worlds. New Media and Society, 3(1), 7-28.

Lim, M. (2002). Cyber-civic Space: From Panopticon to Pandemonium? International Development and Planning Review, 24(4), 383-400. http://dx.doi.org/10.3828/idpr.24.4.3

Lim, M. (2006). Lost in Transition? The Internet and Reformasi in Indonesia. In J. Dean, J. W. Anderson, \& G. Lovink (Eds.), Reformatting Politics: Information Technology and Global Civil Society. London and New York: Routledge.

MacKenzie, D., \& Wajcman, J. (Eds.). (1985). The Social Shaping of Technology: How The Refrigerator Got its Hum. Open University Press, Milton Keynes and Philadelphia.

Manin, B. (1987). On Legitimacy and Political Deliberation. Political Theory, 15. http://dx.doi.org/10.1177/00 90591787015003005

Mansbridge, J., Hartz-Karp, J. F., Matthew, A., \& Gastil, J. (2006). Norms of Deliberation: An Inductive Study. Journal of Public Deliberation, 2. Retrieved from http://services.bepress.com/jpd/vol2/iss1/art7

Marcus, D. L. (1998). Indonesia Revolt Was Net Driven. Retrieved May 12, 1998, from http://www.nettime.org

Mele, C. (2005). Cyberspace and Disadvantaged Communities The Internet as a Tool for Collective Action. In M. A. Smith, \& P. Kollock (Eds.), Communities in Cyberspace. London: Routledge.

Melville, K. et al. (2005). National Issues Forums: A Network of Communities. In J. Gastil, \& P. Levine (Eds.), The Deliberative Democracy Handbook. San Francisco: Jossey-Bass.

Mendelberg, T. (2002). The Deliberative Citizen: Theory and Evidence. Political Decision Making, Deliberation, and Participation, 6, 153.

Milliken, M., Gibson, K., \& O'Donnell, S. (2008). User-Generated Video and the Online Public Sphere: Will YouTube Facilitate Digital Freedom of Expression in Atlantic Canada? American Communication Journal (A publication of the American Communication Association), 10(3). Retrieved from http://acjournal.org/ holdings/vol10/03_Fall/articles/milliken_etal.php 
Mnookin, J. L. (1996). Virtual(ly) Law: The Emergence of Law in Lambda MOO. Journal of Computer-Mediated Communication, 2(l). Retrieved from http://jcmc.huji.ac.il/vol2/issuel/

Morrisett, L. (2003). Technologies of freedom? In H. Jenkins, \& D. Thorburn (Eds.), Democracy and New Media. Cambridge, MA: MIT Press.

Nicholas, Y. (2009). Internet and Identity: How a Generation Who Grew up With the Internet Established Identity.

Nugroho, Y. (2009). Hubs and Wires: Internet use in Indonesian NGOs is strengthening civil society Inside Indonesia. Retrieved from http://www.insideindonesia.org/edition-95/hubs-and-wires

Nugroho, Y. (2011). @ksi Warga: Kolaborasi,Demokrasi Partisipatoris dan Kebebasan Informasi-Memetakan Aktivisme Sipil Kontemporer dan Penggunaan Media Sosial di Indonesia. Laporan. Kolaborasi penelitian antara Manchester Institute of Innovation Research, University of Manchester dan HIVOS Regional Office Southeast Asia. Manchester dan Jakarta: MIOIR dan HIVOS.

Nugroho, Y., \& Tampubolon, G. (2008). Network Dynamics in the Transition to Democracy: Mapping Global Networks of Contemporary Indonesian Civil Society. Sociological Research Online, 13(5).

Nussbaum, M. C. (1995). Emotions and Women's Capabilities. In M. C. Nussbaum, \& J. Glover (Eds.), Women, Culture, and Development. Oxford: Oxford University Press. http://dx.doi.org/10.1093/0198289642. 001.0001

Ó Baoill, A. (2004). Weblogs and the Public Sphere. In L. J. Gurak, S. Antonijevic, L. Johnson, C. Ratliff, \& J. Reyman (Eds.), Into the Blogosphere: Rhetoric, Community, and Culture of Weblogs. Retrieved from http://blog.lib.umn.edu/blogosphere/weblogs_and_the_public_sphere.html

Papacharissi, Z. (2002a). The Self Online: The Utility of Personal Home Pages. Journal of Broadcasting and Electronic Media, 46(3), 346-368. http://dx.doi.org/10.1207/s15506878jobem4603 3

Papacharissi, Z. (2002b). The Presentation of Self in Virtual Life: Characteristics of Personal Home Pages. Journalism and Mass Communication Quarterly, 79(3), 643-660. http://dx.doi.org/10.1177/107769900 207900307

Pateman, C. (1970). Participation and Democratic Theory. Cambridge: Cambridge University Press. http://dx. doi.org/10.1017/cbo9780511720444

Podhoretz, J. (2002). The Internet's First Scalp. New York Post.

Prior, M. (2007). Post-Broadcast Democracy: How Media Choice Increases Inequality in Political Involvement and Polarizes Elections. New York: Cambridge University Press. http://dx.doi.org/10.1017/cbo9781 139878425

Rasmussen, T. (2009). The Significance of Internet Communication in Public Deliberation. Digitising the Public Sphere, 16(1). http://dx.doi.org/10.1080/13183222.2009.11008995

Reedy, J., \& Wells, C. (2009). Information, The Internet, and Direct Democracy. In A. Chadwick, \& N. Philip (Eds.), Routledge Handbook of Internet Politics. New York and Canada: Routledge 2 Park Square.

Reid, E. (2005). Hierarchy and Power Social Control in Cyberspace. In M. A. Smith, \& P. Kollock (Eds.), Communities in Cyberspace. London: Routledge.

Rheingold, H. (1993). The Virtual Community: Homesteading on the Electronic Frontier. Reading, MA: Addison-Wesley.

Rorty, A. O. (1985). Varieties of Rationality, Varieties of Emotion. Social Science Information, 24, 343-353. http://dx.doi.org/10.1177/053901885024002010

Roth, M. M. (2004). How Journalists See the Blogosphere. Retrieved from http://www.asc.upenn.edu/usr/ mmccoy/blogs.pdf

Sanders, L. M. (1997). Against Deliberation. Political Theory, 25, 347-376. http://dx.doi.org/10.1177/ 0090591797025003002

Schalken, K. (2000). Virtual Communities: New Public Spheres on the Internet? In J. Hoff, I. Horrocks, \& P. Tops (Eds.), Democratic Governance and New Technology. London: Routledge. http://dx.doi.org/10.4324/9 780203449738_chapter_10

Schrum, L. (1997). Ethical Research in the Information Age: Beginning the Dialog. Computers in Human 
Behavior, 13(2), 117-125. http://dx.doi.org/10.1016/S0747-5632(97)80001-5

Setälä, M., \& Grönlund, K. (2005). Parliamentary Websites: Theoretical and Comparative Perspectives. European Consortium for Political Research General Conference. Budapest, September.

Shah et al. (2001). Connecting and Disconnecting with Civic Life: Patterns of Internet Use and the Production of Social Capital. Political Communication, 18(2), 141-162. http://dx.doi.org/10.1080/105846001750322952

Sikka, T. (2006) The Public Sphere, Globalization and Technological Development. Retrieved from http://www.sidint.org/development

Smith, M. A., \& Kollock, P. (2005). Communities in Cyberspace. London: Routledge.

Smolkin, R. (2004). The Expanding Blogosphere. American Journalism Review, 26(3), 38-44.

Smuts, L. M. (2010). Social Networking Sites as a New Public Sphere: Facebook and its Potential to Facilitate Public Opinion as the Function of Public Discourse-A Case Study of the 2008 Obama Campaign. Partial Fulfilment of the Requirements for the Degree of M.Phil (Political Management) at Stellenbosch University.

Snee, H. (2008). Social Sciences Collections and Research: Web 2.0 as a Social Science Research Tool. Retrieved from http://ww.bl.uk/reshelp/bldept/socsci/socint/web2/web2.pdf

Sproull, L., \& Faraj. (1995). Atheism, Sex, and Databases: The Net as a Social Technology. In B. Kahin, \& J. Keller (Eds.), Public Access to the Internet. Cambridge, MA: MIT Press.

Sunstein, C. (2001). Republic.com. Princeton: Princeton University Press.

Tedjabayu. (1999). Indonesia: The Net as a Weapon. Cybersociology Magazine.

Thompson, S., \& Hoggett, P. (2001). The Emotional Dynamics of Deliberative Democracy. Policy and Politics, 29, 351-364. http://dx.doi.org/10.1332/0305573012501396

Thornton, A. (2002). Does Internet Create Democracy? Retrieved from http://www.zipworld.com.au/ athornto/thesis_2002_alinta_thornton.doc

Tilly, C. (1978). From Mobilization to Revolution. New York: Random House.

Turkle, S. (1995). Life on the Screen: Identity in the Age of the Internet. New York: Simon \& Schuster.

Ubayasiri, K. (2006). Internet and the Public Sphere: A Glimpse of YouTube. Central Queensland University.

Uslaner, E. M. (2004). Trust, Civic Engagement and the Internet. Political Communication, 1(2) 223-242. http://dx.doi.org/10.1080/10584600490443895

van den Boomen, M. (1998). Virtual Communities and Social Reality 2/2. Nettime.org (31 July 1998).

van Stokkom, B. (2003). Deliberative Group Dynamics: Power, Status, and Affect in Interactive Policy making., Policy and politics.

Wallsten, K. (2007). Agenda Setting and the Blogosphere: An Analysis of the Relationship between Mainstream Media and Political Blogs. Review of Policy Research, 24, 567-587. http://dx.doi.org/10.1111/j.1541-1338. 2007.00300.x

Walther, J. B. (2002). Research Ethics in Internet-Enabled Research: Human Subjects Issues and Methodological Myopia. Ethics and Information Technology, 4(3), 205-216. http://dx.doi.org/10.1023/A:1021368426115.

Warren, M. (1992). Democratic Theory and Self-transformation. American Political Science Review, 86, 8-23. http://dx.doi.org/10.2307/1964012

Wilhelm, A. G. (1999). Virtual Sounding Boards: How Deliberative is Online Political Discussion? In B. N. Hague, \& B. D. Loader (Eds.), Digital Democracy: Discourse and Decision Making in the Information Age (pp. 154-177). London: Routledge.

Williams, M., \& Robson, K. (2003). Re-engineering Focus Group Methodology for the Online Environment. In S. L. Chen, \& J. Hall (Eds.), Online Social Research: Methods, Issues and Ethics. New York: Peter Lang.

Wong, L. (2002). The Internet, Politics and The Digital Divide In Asia. International Conference on the Digital Divide: Technology \& Politics in the Information Age, University of Newcastle New South Wales, Australia. 


\section{Copyrights}

Copyright for this article is retained by the author(s), with first publication rights granted to the journal.

This is an open-access article distributed under the terms and conditions of the Creative Commons Attribution license (http://creativecommons.org/licenses/by/3.0/). 